\title{
A prospective randomized comparative study of intra-cervical Foley's catheter insertion versus PGE2 gel for pre-induction cervical ripening
}

\author{
Manisha M. Laddad*, Nitin S. Kshirsagar, Anand V. Karale
}

Department of Obstetrics \& Gynecology, Krishna Institute of Medical Sciences, Karad, Maharashtra, India

Received: 6 April 2013

Accepted: 14 April 2013

\section{*Correspondence:}

Dr. Manisha M. Laddad,

E-mail: drmanishald@gmail.com

(C) 2013 Laddad MM et al. This is an open-access article distributed under the terms of the Creative Commons Attribution License, which permits unrestricted use, distribution, and reproduction in any medium, provided the original work is properly cited.

\section{ABSTRACT}

Background: The success of induced labor depends on the degree of ripening of cervix. Pharmacological preparations are in widespread use for cervical ripening but are not free from side-effects and complications. Mechanical methods, i.e. the use of Foley catheter balloon, though effective have not gained much popularity because of the fear of infection. Therefore, this study has been conducted to prove the efficacy and safety of extra amniotic Foley catheter balloon and to compare it with intracervical prostaglandin E2 (PGE2) gel.

Aims and objectives: The success of induction of labor depends on the cervical status at the time of induction. Objective for effective cervical ripening both Foley's catheter and $\mathrm{PGE}_{2}$ gel are used. The aim of this study was to compare the efficacy of intra cervical Foley's catheter and intra cervical $\mathrm{PGE}_{2}$ gel in cervical ripening for the successful induction of labor.

Methods: A randomized, prospective study was conducted in the Dept of OBGY, Krishna institute of medical sciences, deemed university Karad, from January 2011-December 2012. 400 patients at term with a Bishop's score <3 with various indications for induction were randomly allocated to receive (200 pts) intra-cervical Foley's catheter or $\mathrm{PGE}_{2}$ gel (200 pts). After $6 \mathrm{~h}$ post induction, Bishop's score was noted labor was augmented if required. Statistical analysis was done using Chi square test and test.

Results: The groups were comparable with respect to maternal age, gestation age, indication of induction and initial Bishop's score. Both the groups showed significant change in the Bishop's score, $5.54 \pm 1.89$ and $5.44 \pm 1.82$ for Foley's catheter and $\mathrm{PGE}_{2}$ gel, respectively, $\mathrm{P}<0.001$; However there was no significant difference between the two groups. There was no significant difference in the side effects and caesarean section rate in both groups. The induction to delivery interval was $15.34 \pm 5.24 \mathrm{~h}$ in Group A and $14.2 \pm 5.24 \mathrm{~h}$ in Group B $(p=0.291)$. Apgar scores, birth weights and NICU admissions showed no difference between the two groups.

Conclusions: This study shows that both Foley's catheter and $\mathrm{PGE}_{2}$ gel are equally effective in pre induction cervical ripening.

Keywords: Cervical ripening, $\mathrm{PGE}_{2}$, Foley's catheter, Induction of labor

\section{INTRODUCTION}

Cervical ripening refers to a process of preparing the cervix for induction of labor by promoting effacement and dilatation as measured by Bishop's score. ${ }^{1}$ The success of labor induction depends on the cervical status at the time of induction. It is generally predicted that the patients with a poor Bishop's score $\leq 3$ have unacceptably higher rates of failure of induction. ${ }^{2,3} \mathrm{It}$ was also shown that a low Bishop's score is associated with increased rates of cesarean sections, maternal fever and fetal asphyxia. ${ }^{1,2}$ To decrease the induction failure, 
cervical ripening by any methods is the answer. It then addresses methods used to hasten cervical ripening and to induce labor, ranging from the more "natural" and noninvasive methods, such as nipple stimulation, to the newest commercially available formulation of prostaglandin. ${ }^{3,4}$

The purpose of this study was to compare the efficacy of intra-cervical Foley's catheter with $\mathrm{PGE}_{2}$ gel for preinduction cervical ripening. The induction delivery interval, maternal and fetal outcomes and the need for augmentation of labor in or these two groups were also compared.

\section{METHODS}

The present prospective study was conducted at KIMSDU; Karad in the department of OBGY from January 2011-Dec 2012. It was approved by Ethical committee of the institution. The study population $(\mathrm{n}=$ 400) was a mixture of high and low risk population. Patients at term with various indications for induction of labor were included in the study after a written, valid consent.

\section{Inclusion criteria:}

(a) Primigravida

(b) $\quad \geq 37$ weeks of gestation

(c) Singleton pregnancy

(d) Cephalic presentation

(e) Bishops score $\leq 3$

(f) Intact membranes

\section{Exclusion criteria:}
(a) Multiple pregnancy
(b) Mal-presentation
(c) Absent membranes
(d) $\mathrm{APH}$
(e) Medical disease e.g., heart disease, renal disease.
(f) Previous LSCS

The patients were randomly allocated to either Foley's catheter (Group A, n = 200), $\mathrm{PGE}_{2}$ gel (Group B, n =200) method. The Bishop's score was determined earlier. Each patient was questioned in detail and examined thoroughly. Last menstrual period (LMP) was ascertained and correlated clinically.

Post induction Bishop's score was assessed after $6 \mathrm{~h}$ of induction preferably by the same person.

Demographic profile, gestation age, improvement of Bishop's score, induction-delivery interval, mode of delivery and feto-maternal outcome was noted.

Dose repetition of $\mathrm{PGE}_{2}$ gel was considered if postinduction Bishop's score was $\leq 6$ in both the groups.
Need of augmentation of labor was assessed and implemented by other methods such as acute rupture of membrane (ARM) and/or oxytocin administration.

Failure of induction was declared if patient failed to go in active phase of labor within $48 \mathrm{~h}$ of induction.

Student's $\mathrm{t}$ test and Chi square test were used to statistically compare the two groups. Differences with a $p$ value of $<0.05$ were considered statistically significant with the confidence limit of $95 \%$ (power of test $80 \%$ ).

\section{RESULTS}

Group A and Group B had 200 randomized patients each. Both the groups were comparable with respect to the maternal age, gestational age, indication for induction and pre-induction Bishop's score (Tables 1,2).

Table 1 Demographic profile.

\begin{tabular}{|llll|}
\hline Variable & $\begin{array}{l}\text { Group A } \\
(\mathbf{n = 2 0 0 )}\end{array}$ & $\begin{array}{l}\text { Group B } \\
(\mathbf{n}=200)\end{array}$ & $p$ \\
\hline Maternal age & $\begin{array}{l}21.27 \pm \\
2.97\end{array}$ & $\begin{array}{l}21.00 \pm \\
2.79\end{array}$ & 0.079 \\
& $\begin{array}{l}38.7 \pm \\
1.73\end{array}$ & $\begin{array}{l}38.9 \pm \\
1.68\end{array}$ & 0.11 \\
\hline Gestation age & $78(39 \%)$ & $74(37 \%)$ \\
& $60(30 \%)$ & $57(28.5 \%)$ \\
\hline Indication for induction \\
\hline PIH & $12(6 \%)$ & $14(7 \%)$ & \\
\hline Post-datism & $10(5 \%)$ & $5(2.5 \%)$ \\
\hline IUGR & $10(5 \%)$ & $15(7.5 \%)$ \\
\hline Oligohydramnios & $30(15 \%)$ & $35(17.5 \%)$ & \\
\hline IUFD & $1.48 \pm$ & $1.59 \pm$ & $>0.005$ \\
\hline Others & 0.67 & 0.78 & \\
\hline Mean pre-induction & & \\
score & &
\end{tabular}

No statistically significant difference was demonstrated between the two groups.

In this present study improvement in the Bishop's score in Group A was $5.54 \pm 1.89$ (mean $\pm \mathrm{SD}, p<0.001$ ) and in Group B it was $5.44 \pm 1.82$ (mean db SD, $p<0.001$ ); however no significant difference in the mean changes in the two groups could be established (Table 2).

Table 2: Change in Bishop score.

\begin{tabular}{|lll|}
\hline Bishops score & $\begin{array}{l}\text { Group A } \\
(\mathbf{n}=\mathbf{2 0 0})\end{array}$ & $\begin{array}{l}\text { Group B } \\
(\mathbf{n}=\mathbf{2 0 0})\end{array}$ \\
\hline $\begin{array}{l}\text { Mean pre-induction } \\
\text { score }\end{array}$ & $1.48 \pm 0.67$ & $1.59 \pm 0.78$ \\
\hline $\begin{array}{l}\text { Mean post-induction } \\
\text { score }\end{array}$ & $7.04 \pm 1.72$ & $7.08 \pm 1.87$ \\
\hline $\begin{array}{l}\text { Mean change in } \\
\text { score }\end{array}$ & $5.54 \pm 1.89$ & $5.44 \pm 1.82$ \\
\hline & $\mathrm{t}=20.91$ & $\mathrm{f}=40.17$ \\
\hline & $p<0.0001$ & $p<0.0001$ \\
\hline
\end{tabular}


The need for further augmentation of labor was studied in this study (Table 3). Spontaneous labor ensued in 50 patients in Group A (25\%) compared with 56 patients in Group B (28\%). In Foley's catheter group, need for augmentation of labor was required by doing ARM $(n=18)$ oxytocin infusion $(n=78)$ and both ARM + oxytocin 54(27\%) patients required. In $\mathrm{PGE}_{2}$ gel group, 22 patients required ARM, 76 patients required oxytocin and 46 patients required both ARM + oxytocin. There was no significant difference in need for augmentation in both groups.

Table 3: Need for augmentation.

\begin{tabular}{|llll|}
\hline $\begin{array}{l}\text { Mode of } \\
\text { delivery }\end{array}$ & $\begin{array}{l}\text { Group A } \\
(\mathbf{n}=200)\end{array}$ & $\begin{array}{l}\text { Group B } \\
(\mathbf{n}=200)\end{array}$ & $\begin{array}{l}\boldsymbol{p} \text { value } \\
\mathbf{X}^{2} \text { test }\end{array}$ \\
\hline Spontaneous & $50(25 \%)$ & $56(28 \%)$ & $\mathrm{I} 2=4.45$ \\
\hline ARM & $18(9 \%)$ & $22(11 \%)$ & $\mathrm{df}^{3}$ \\
\hline Oxytocin & $78(39 \%)$ & $76(38 \%)$ & $p=0.21$ \\
\hline $\begin{array}{l}\text { ARM + } \\
\text { oxytocin }\end{array}$ & $54(27 \%)$ & $46(23 \%)$ & \\
\hline Total & 200 & 200 & 400 \\
\hline
\end{tabular}

No significant difference in need for augmentation in both groups.

Table 4 shows no significant statistical difference in spontaneous vaginal delivery in both the groups. Group A had 79\% ( $\mathrm{n}=158)$ spontaneous deliveries whereas Group $\mathrm{B}$ had $77.5 \%(\mathrm{n}=155)$ spontaneous deliveries.

Table 4: Mode of delivery and induction-delivery interval.

\begin{tabular}{|llll|}
\hline Variable & $\begin{array}{l}\text { Group A } \\
(\mathbf{n}=200)\end{array}$ & $\begin{array}{l}\text { Group B } \\
(\mathbf{n}=\mathbf{2 0 0})\end{array}$ & $\boldsymbol{p}$ value \\
\hline Spontaneous & $158(79 \%)$ & $\begin{array}{l}155 \\
(77.5 \%)\end{array}$ & $\mathrm{I}^{2}=1-68$ \\
\hline Instrumental & $7(3.5 \%)$ & $5(2.5 \%)$ & $\mathrm{df}^{2}$ \\
\hline LSCS & $\begin{array}{l}35 \\
(17.5 \%)\end{array}$ & $40(20 \%)$ & $p=0.438$ \\
\hline Total & 200 & 200 & \\
\hline $\begin{array}{l}\text { Induction- } \\
\text { delivery } \\
\text { interval }\end{array}$ & $15.34 \pm$ & $14.2 \pm$ & $\mathrm{t}=1.059$ \\
& 5.24 & 5.24 & $p=0.291$ \\
\hline
\end{tabular}

The need for operative intervention (LSCS) was also not significant in both the groups. LSCS was done for fetal distress in Group A for 18 cases and in Group B for 21 cases. The other indications for LSCS being failure to progress (10 and 13 respectively and failure of induction (1 and 3 respectively).

Table 5 shows the incidence of perinatal asphyxia with Apgar score $\leq 7$ at $5 \mathrm{~min}$ and me conium aspiration syndromes were similar in both the groups. The neonatal birth weights were also comparable in both the groups $(2.47 \pm 0.44$ in Group A and $2.58 \pm 0.48$ in Group B). $18.5 \%$ of babies in Group A $(n=38)$ and $21 \%$ of babies in Group B ( $\mathrm{n}=43)$ got admitted in NICU. However the morbidity in both the groups was not statistically significant.

Table 5: Neonatal outcome.

\begin{tabular}{|llll|}
\hline Variable & $\begin{array}{l}\text { Group A } \\
(\mathbf{n = 2 0 0})\end{array}$ & $\begin{array}{l}\text { Group B } \\
(\mathbf{n = 2 0 0})\end{array}$ & $\boldsymbol{p}$ value \\
\hline MAS & 8 & 10 & $\begin{array}{l}>0.05 \\
(\mathrm{NS})\end{array}$ \\
\hline LSCS for FD & 18 & 21 & \\
\hline 1 min Apgar $<7$ & 20 & 22 & \\
\hline 5 min Apgar $<7$ & 14 & 17 & \\
\hline NICU admission & 38 & 43 & \\
\hline Neonatal deaths & 6 & 8 & \\
\hline
\end{tabular}

\section{DISCUSSION}

The results of this study confirm that both Foley's catheter and $\mathrm{PGE}_{2}$ gel are equally effective in preinduction cervical ripening. The mean change in Bishops score in Foleys catheter $5.54 \pm 1.89(p<0.0001)$ and $\mathrm{PGE}_{2}$ gel $5.44 \pm 1.82(p<0.0001)$ were highly significant. ${ }^{3,4}$ However, a comparison between the groups revealed that one method did not confer a statistically significant advantage over the other. There have been theoretic concerns regarding the introduction of infection with the use of Foley's catheter. In this study there was no infectious morbidity. Similar were the observation of St. Onge and Conners, Jozwiak $M,{ }^{4,7}$ and Anthony Alfirevic Z et al. ${ }^{5,6}$

The need for oxytocin induced augmentation of labor was $39 \%$ in Group A and $38 \%$ in Group B. This is in agreement with studies done by Hertelendy $\mathrm{F}$ et al. ${ }^{8}$

The induction delivery interval showed no significant difference in the two groups. The mean I-D internal was 15.34 h in Foley's group and $14.2 \mathrm{~h}$ in $\mathrm{PGE}_{2}$ group. Similar observations were observed by Pennel $\mathrm{C}$ et al. ${ }^{9}$

The rate of LSCS in Group A was $17.5 \%$ and $20 \%$ in Group B ( $p=0.438$, NS). The most common indication for LSCS in Group A was fetal distress. Group A had 18 cases for FD and Group B had 21 cases of FD. The rate of LSCS in our study is agreeable. ${ }^{6,9}$ There was no association of increased rate of cesarean section with the Foley's catheter $\mathrm{PGE}_{2}$ gel use. ${ }^{8,9}$

Fetal outcome data showed no significant difference between Group A and Group B with respect to birth wt $(2.67 \pm 0.44$ and $2.58, /=4.28,3 \mathrm{df}, p=0.188)$, MAS $(8$ and 10 respectively), 1 min Apgar score <7 (14 and 17 respectively), NICU admission rate (38 and 43 respectively). Thus the present study shows that the fetal outcome results were also comparable in both the groups. ${ }^{7,9}$

The total cost of Foley's catheter was much less than $\mathrm{PGE}_{2}{ }^{6,9}$ 


\section{CONCLUSION}

In conclusion this study has shown that for pre-induction cervical ripening there is no difference in efficacy between intra cervical $\mathrm{PGE}_{2}$ gel and intra cervical Foley's catheter. Also, other factors like induction delivery interval maternal and neonatal outcome and need for oxytocin for further augmentation were similar in both the groups. Both methods are complementary to each other.

\section{ACKNOWLEDGEMENTS}

We thank Medical Director, KIMSDU, Karad for allowing us to use and publish the data related to patients.

Funding: No funding sources

Competing interests: None

Ethical approval: The study was approved by the ethical committee of the institute

\section{REFERENCES}

1. World Health Organization, Department of reproductive health and research. WHO recommendations for induction of labour. Geneva, Switzerland: World Health Organisation; 2011:32.

2. National Institute for Clinical Excellence. Clinical guidelines for induction of labor, Appendix-E. London: NICE; 2001.
3. St. Onge RD, Conners GT. Preinduction cervical ripening: a comparison of intracervical PGE2 gel vs. the Foley catheter. Am J Obstet Gynecol 1995;172:687-90.

4. Dewan F, Ara AM, Begum A. Foley's catheter versus prostaglandin for induction of labor. Singap J Obstet Gynaecol 2001;32:56-63.

5. Anthony C, Sciscione DO, Helen M, et al. A prospective, randomized comparison of Foley catheter insertion vs. intracervical PGE2 gel for preinduction cervical ripening. Am J Obstet Gynecol 1999;180:55-9.

6. Alfirevic Z, Kelly A, Dowsell T. Intravenous oxytocin alone for cervical ripening and induction of labour. Cochrane Database Systematic Rev 2009;(4):Art. No.: CD003246.

7. Jozwiak M, Bloemenkamp K, Kelly A, Mol B, Irion O, Boulvain M. Mechanical methods for induction of labour. Cochrane Database Systematic Rev 2012;(3):Art. No.: CD001233.

8. Hertelendy F, Zakar T. Prostaglandins and the myometrium and cervix. Prostaglandins Leukot Essent Fatty Acids 2004;70:207-22.

9. Pennell C, Henderson J, O’Neill M, McCleery S, Doherty D, Dickinson J. Induction of labour in nulliparous women with an unfavourable cervix: a randomised controlled trial comparing double and single balloon catheters and PGE2 gel. BJOG 2009;116:1443-52.

DOI: $10.5455 / 2320-1770$. ijrcog20130622

Cite this article as: Laddad MM, Kshirsagar NS, Karale AV. A prospective randomized comparative study of intra-cervical Foley's catheter insertion versus PGE2 gel for pre-induction cervical ripening. Int J Reprod Contracept Obstet Gynecol 2013;2:217-20. 